\title{
Knowledge and Practice of Family Caregiver for Clients Using Vacuum Wound Therapy for Infected Limb Surgical Wound
}

\author{
SOHEIR ABO ELFOTOUH, M.Sc.; NAGAT SAID, D.N.Sc. and ENAS HELMY, D.N.Sc. \\ The Department of Community Health Nursing, Faculty of Nursing, Cairo University, Cairo, Egypt
}

\begin{abstract}
Background: Family caregivers had heavy burden and a lot of great responsibilities toward their clients using vacuum wound therapy.
\end{abstract}

Aim of Study: To asses knowledge and practice of family caregiver for clients using vacuum wound therapy for infected limb surgical wound. design.

Material and Methods: Design: A descriptive research

Setting: Out patient emergency plastic surgical clinic which affiliated to emergency hospital 185 at Cairo university hospital.

The Study Sample: A convenient sample of 61 family caregivers and their (61) clients used vacuum wound therapy were included in the study from August 2017 to March 2018

Tool for data collection: One tool "Clients and family caregivers a Structured interview questionnaire" which divided to four parts. Part (I): Demographic characteristics of the family caregivers and clients. Part (II): Medical history of clients and home environment. Part (III): Family caregiver knowledge about vacuum wound therapy part (IV): Family caregiver practice about vacuum wound therapy. The total knowledge and practice scores for questionnaires are 100 .

Results: $42.6 \%$ of family caregivers age from 20 to less than 30 years and $73.7 \%$ of them were male. The result revealed that positive statistically significant relations between total knowledge of family caregivers and their age, $p=0.02$. And education level, $p=0.07$. There was a positive statistical significant total practice and their job, $p=0.08$.

Conclusion: The study concluded that, $51 \%$ of them had unsatisfactory total knowledge. Total practice $53 \%$ of them had satisfactory score while $47 \%$ of them had unsatisfactory score of total practices regarding vacuum wound therapy.

Recommendations: The study recommended before application therapy, knowledge should be developed for family caregiver about definition, uses, benefits and initiation of therapy Improve practice of family caregiver to manage therapy through demonstration and training on safe handling

Correspondence to: Dr. Soheir Abo Elfotouh,

The Department of Community Health Nursing,

Faculty of Nursing, Cairo University, Cairo, Egypt of infectious and hazardous waste are critical to prevent cross contamin ation.

Key Words: Family caregiver client-Injury - Vacuum wound therapy.

\section{Introduction}

INJURIES due to trauma result in indirect costs to the individual, family and community. Indirect costs of injury may include family needing to take time off work and pay for accommodation close to the treatment and pay for food. Non-quantifiable costs of injury include emotional trauma, permanent partial or full disability, altered career implications, dramatic changes in future roles in family and society, loss of independent living and the necessity for institutional care [1].

Thousands of people are killed and injured due to accident, every day. Men, women or children walking, biking or riding to school or work, playing in the streets may never return home and would leave behind shattered families and communities [2].

Vacuum wound therapy is also known as subatmospheric pressure (SAP), topical negative pressure (TNP), vacuum-assisted closure (V.A.C.), and micro-deformational wound therapy (MDWT), and has greatly impacted the field of wound and surgical care [3]. The devices are classified as either powered or batteries It was applying continuous or intermittent topical negative pressure to a special dressing positioned in the wound cavity. It is designed to help provide a closed, moist, sterile environment, help remove exudate from the wound, stimulate the growth of healthy granulation tissue and aids wound contraction [4]

Also, it is a method that improves the healing process could greatly decrease the risk of infection, 
amputation, and length of hospital stay. is a technology that is currently widely used in wound care and is promoted for use on complex wounds. NPWT involves the application of a wound dressing through application of negative pressure often with any wound and tissue fluid drawn away from the area being collected into a jar. The amount of pressure applied using the therapy can vary and there is no single protocol for use however, pressure being delivered ranges from $75 \mathrm{mmHg}$ to $150 \mathrm{mmHg}$ with $125 \mathrm{mmHg}$ being commonly used [5]

Family caregivers are critical partners in the plan of care for clients with limb injury they are responsible for the physical, emotional and often financial support of another person who is unable to care for him/herself due to illness or injury [6]

Family Caregivers who are employed report missed days, interruptions at work, leaves of absence, and reduced productivity because of their caregiving obligations Low personal and household incomes and limited financial resources can result in increased family caregiver risk for negative outcomes financial concerns cause particular distress for family caregivers during long treatment periods [7].

The nurses with orientation regarding the new technologies in wound management. Using VAC therapy with certain types of wound has many positive outcomes such as enhanced healing and granulation tissue formation; management of highly exuding wounds; reduced dressing changes compared with more conventional dressings; reduced nurse time; reduced costs; and improved quality of life [8].

\section{Subjects and Methods}

Aim of the study:

The aim of this study was to asses knowledge and practice of family caregivers for clients using vacuum wound therapy for infected limb surgical wound.

\section{Research question:}

To fulfill the aim of this study the following research questions are formulated:

1- What is the knowledge of family caregivers for client using vacuum wound therapy for infected limb surgical wound?

2- What is the practice of family caregivers for client using vacuum wound therapy for infected limb surgical wound?

\section{Research design:}

A descriptive exploratory research design was utilized to achieve the aim of this study.

Setting:

The study was conducted at out patient emergency plastic surgical clinic which affiliated to emergency hospital 185 at Cairo University Hospital, it was established since July 2014 and received patients post trauma. Its classified into two main parts, in patient and out patient clinic. Inpatient include specific specialty as surgery, orthopedic, vascular, urology, burn and cardio thoracic also intensive care units, resuscitation room and operating room. The out patient emergency hospital 185 its inside in Surgical out patient clinic which divided into two unit A\& B, each unit provides services as follow plastic surgery at Saturday and Tuesday, vascular surgery at Sunday and Wednesday and general surgery at Monday and Thursday. There are weekly rotations for each unit and shifting was occur. The unit A consist of five rooms, two rooms for dressing one of them use for patient use vacuum wound therapy, one room for sterilization and preparing surgical equipment, one room for examination and one room for nursing staff. Routine working time from $8 \mathrm{a} . \mathrm{m}$. to 1p.m. The health team at unit consist of four nurses, one resident doctor, one assistant lecturer and one to two internship physicians. Unit B consist of five rooms, two rooms for dressing one of them use for patient use vacuum wound therapy, one room for sterilization and preparing surgical equipment, one room for examination and one room for nursing staff and one room for training and education medical staff. The health team at unit consist of six nurses, one resident doctor, one assistant lecturer and one to two internship physicians. The two room near social workers office, nursing director office and minor operation room.

\section{Sample:}

Convenient sample consists of 61 family caregivers and their (61) clients with upper or lower limb injury using vacuum wound therapy at home and family caregivers at emergency plastic surgical clinic at emergency hospital 185 for follow-up 8 consecutive months of the study. All the family caregivers were voluntarily into study after a careful explanation of the objectives of the study. All family caregivers and their clients was attending 2 days every week at Saturday and Tuesday.

\section{Inclusion criteria:}

1- Clients who live near Cairo University Hospital in Egypt who suffering from infected limb 
surgical wound and using vacuum wound therapy.

2- Family care who willing to participate in this study.

\section{Tools of data collection:}

The researcher was used one tool divided to four parts to collect the current data of the study after review of recent literature and related researches. Clients and family caregivers a Structured interview questionnaire:

The tool was used to assess of knowledge and practice of family caregiver for clients using vacuum wound therapy for infected limb surgical wound. It classified into four parts:

Part (I): It was include demographic characteristic of family caregivers and clients:

- Demographic characteristic of family caregivers as age, sex, level of education, occupation, address, family relation, and income

- Demographic characteristic of clients as age, sex, level of education, occupation, address, number of family members and health insurance.

Part (II): It was include medical history of the clients and their environment:

Medical history of the clients related to the wound limb injury as well as presence of chronic disease as hypertension, diabetes mellitus and, kidney disease, also smoking, site of injury, time of injury, application of machine, medications and transportation-home environment of the clients as numbers of room and windows, sources of water. Disposal sewage, lights, heaters and types of floors.

Part (III): It was include written questions to assess family caregiver knowledge. Its multiple choose about identifying apparatus parts, benefits of apparatus, uses of apparatus and sources of information about initiation and disconnection of apparatus.

The total knowledge scores for questionnaires are $100 \%$. Those who scored more than $90 \%$ satisfactory considered, Scores between $75 \%$ and 90\% considered accepted knowledge and scores less than $75 \%$ are considered unsatisfactory.

Part (IV): Observational check list, to assess family care giver practice through home visit regarding how to care about vacuum wound apparatus at home such as suddenly disconnected the tubes, get rid from wound discharge collected at the apparatus. Availability of equipment, cleaning procedure and disinfected procedure. The total practice scores of this sheet are $100 \%$. Those who are scored more than $75 \%$ are considered satisfactory. The practice scores are less than $75 \%$ are considered unsatisfactory.

Ethical consideration: Primary approval was obtained from the Research and Ethics Committee of Faculty of Nursing, Cairo University. Written informed consent was taken from the participant, after explanatory the nature and purpose of the study. They were informed also that participation in the study was completely voluntary. Additionally, all participants were assured that their anonymity and confidentiality was guaranteed through coding the data. Moreover, participants was informed that the data will not be reused in another research without their permission.

Procedure: Official permission was obtained from hospital/units administrators to conduct the study, names of potential clients who met criteria for possible inclusion was obtained twice weekly from the head nurses of outpatient. Each potential a client and family caregiver are approached individually by the research investigator. At that time, the nature and the purpose of the study as well as the follow-up schedule were explained; in addition to all other ethical considerations mentioned previously. Those who approve to participate in the study was asked to sign the consent form. During initial interview and after the consent has been signed, Socio demographic characteristic, medical history and family care givers knowledge and practice and wound assessment, Check list tool and the investigator were completed during followup clinic visit for each a client.

Statistical analysis: Data were statistically described in terms of frequencies (number of cases) and percentages. Comparison between the study groups was done using Chi-square $\left(\mathrm{X}^{2}\right)$ test. Exact test was used instead when the expected frequency is less than 5. $p$-values less than 0.05 was considered statistically significant. All statistical calculations were done using computer program IBM SPSS (Statistical Package for the Social Science; IBM Corp, Armonk, NY, USA) release 22 for Microsoft Windows.

\section{Results}

Table (1) shows that $41.0 \%$ of clients aged more than or equal 25 years old while $4.9 \%$ aged from 15 to less than 20 years old. $78.7 \%$ of the clients was male and $21.3 \%$ was female. As regard marital status, $59.0 \%$ of clients was single while $1.6 \%$ was widow. Regarding education level, $26.2 \%$ 
of client's had basic education and $1.6 \%$ had diploma. As regarding job, $31.1 \%$ of them did not worked while $1.6 \%$ are employee. Regarding to income, $70.5 \%$ of clients had income less than 500 Egyptian pounds while $4.9 \%$ their income more than 1500 Egyptian pound. Also $96.7 \%$ didn't have enough income while only $3.3 \%$ had enough income.

Table (1): Demographic characteristics of clients using vacuum wound therapy for infected limb surgical wound $(n=61)$.

\begin{tabular}{|c|c|c|}
\hline Variables & No. & Percentage \\
\hline \multicolumn{3}{|l|}{ Age: } \\
\hline Less than 5 & 4 & 6.6 \\
\hline $5>10$ & 12 & 19.7 \\
\hline $10>15$ & 6 & 9.8 \\
\hline $15>20$ & 3 & 4.9 \\
\hline $20<25$ & 11 & 18.0 \\
\hline$>25$ & 25 & 41.0 \\
\hline \multicolumn{3}{|l|}{ Gender: } \\
\hline Male & 48 & 78.7 \\
\hline Female & 13 & 21.3 \\
\hline \multicolumn{3}{|l|}{ Marital status: } \\
\hline Single & 36 & 59.0 \\
\hline Married & 24 & 39.4 \\
\hline Widow & 1 & 1.6 \\
\hline \multicolumn{3}{|l|}{ Educational level: } \\
\hline Can't read and write & 24 & 39.3 \\
\hline Read and write & 11 & 18.2 \\
\hline Basic education & 16 & 26.2 \\
\hline Secondary education & 6 & 9.8 \\
\hline University education & 3 & 4.9 \\
\hline Diploma & 1 & 1.6 \\
\hline \multicolumn{3}{|l|}{ Job: } \\
\hline Employee & 1 & 1.6 \\
\hline Profession & 1 & 1.6 \\
\hline Student & 14 & 23.0 \\
\hline House wife & 8 & 13.2 \\
\hline Not working & 19 & 31.1 \\
\hline Hand craft & 18 & 29.5 \\
\hline \multicolumn{3}{|l|}{ Income: } \\
\hline Less than 500 & 43 & 70.5 \\
\hline $500<1000$ & 5 & 8.2 \\
\hline $1000<1500$ & 10 & 16.4 \\
\hline 1500 & 3 & 4.9 \\
\hline \multicolumn{3}{|l|}{ Enough income: } \\
\hline Yes & 2 & 3.3 \\
\hline No & 59 & 96.7 \\
\hline
\end{tabular}

Table (2) indicates that $42.6 \%$ family caregivers between aged from 20 to less than 30 years old while $4.9 \%$ aged more than or equal 50 years old. In additional $73.7 \%$ of the family caregivers was male and $26.3 \%$ was female. As regard marital status, the family caregivers were married $70.5 \%$ while $29.5 \%$ were single. Regarding education level, $45.9 \%$ family caregivers can't read and write while $1.6 \%$ was university educated. As regard the job of the family caregivers worked as hand craft $60.7 \%$ while $3.3 \%$ of them did not work. Regarding to income, $36.1 \%$ had income less than 500 Egyp- tian pounds and $6.6 \%$ their income from 500 to less than 1000 Egyptian pound. Also 88.5\% did not have enough income and only $11.5 \%$ had enough income.

Table (2): Demographic characteristics of family caregivers for clients using vacuum wound therapy for infected limb surgical wound $(n=61)$.

\begin{tabular}{|c|c|c|}
\hline Variables & No. & Percentage \\
\hline \multicolumn{3}{|l|}{ Age: } \\
\hline Less than 20 & 3 & 4.9 \\
\hline $20>30$ & 26 & 42.6 \\
\hline $30>40$ & 20 & 32.8 \\
\hline $40>50$ & 9 & 14.8 \\
\hline$>50$ & 3 & 4.9 \\
\hline \multicolumn{3}{|l|}{ Gender: } \\
\hline Male & 45 & 73.7 \\
\hline Female & 16 & 26.3 \\
\hline \multicolumn{3}{|l|}{ Marital status: } \\
\hline Single & 18 & 29.5 \\
\hline Married & 43 & 70.5 \\
\hline \multicolumn{3}{|l|}{ Educational level: } \\
\hline Can't read and write & 28 & 45.9 \\
\hline Read and write & 22 & 36.1 \\
\hline Basic education & 4 & 6.6 \\
\hline Secondary education & 6 & 9.8 \\
\hline University education & 1 & 1.6 \\
\hline \multicolumn{3}{|l|}{ Job: } \\
\hline Employee & 3 & 4.9 \\
\hline Student & 4 & 6.6 \\
\hline House wife & 15 & 24.5 \\
\hline Not working & 2 & 3.3 \\
\hline Hand craft & 37 & 60.7 \\
\hline \multicolumn{3}{|l|}{ Income: } \\
\hline Less than 500 & 22 & 36.1 \\
\hline $500<1000$ & 4 & 6.6 \\
\hline $1000<1500$ & 22 & 36.1 \\
\hline 1500 & 13 & 21.3 \\
\hline \multicolumn{3}{|l|}{ Enough income: } \\
\hline Yes & 7 & 11.5 \\
\hline No & 54 & 88.5 \\
\hline Total & 61 & 100 \\
\hline
\end{tabular}

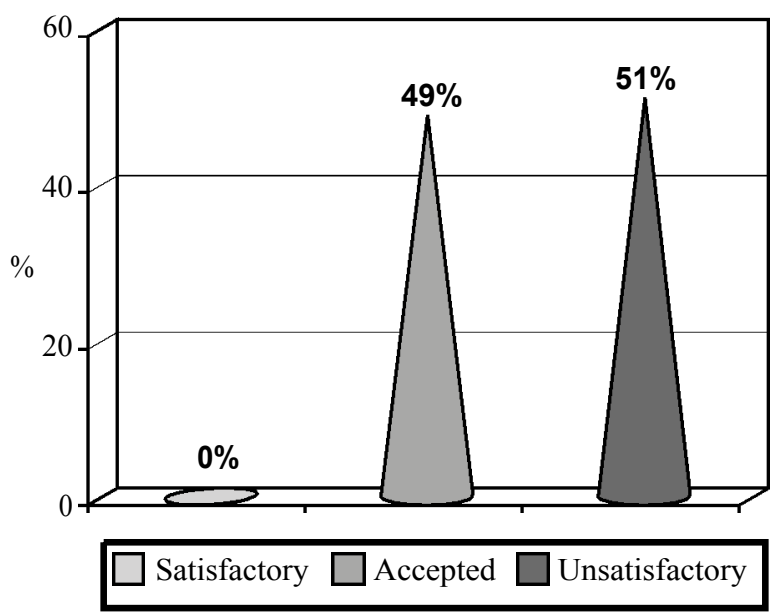

Fig. (1) Total knowledge score of family caregiver. 
Total practice of family scor caregivers

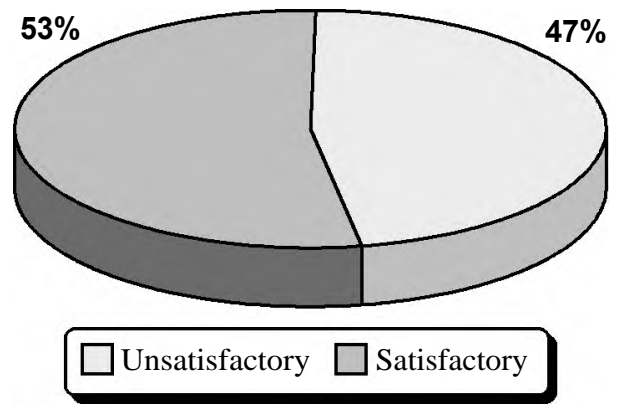

Fig. (2): Total practice of family caregiver

Table (3): Demographic characteristics and home environment of Clients.

\begin{tabular}{lllll}
\hline \multirow{2}{*}{ Variables } & \multicolumn{2}{c}{ Total knowledge } & \multicolumn{2}{c}{ Total practice } \\
\cline { 2 - 5 } & $\chi^{2}$ & $p$ & $\chi^{2}$ & $p$ \\
\hline Age & 11.4 & $0.02^{*}$ & 1.25 & 0.87 \\
Gender & 1.18 & 0.27 & 6.5 & 0.01 \\
Job & 5.6 & 0.33 & 9.6 & $0.08^{*}$ \\
Income & 4.3 & 0.22 & 0.91 & 0.82 \\
Education level & 8.4 & $0.07 *$ & 3.8 & 0.43 \\
Marital status & 0.22 & 0.42 & 3.8 & 0.43 \\
Water sources & 1.05 & 0.30 & 0.92 & 0.33 \\
Sewage disposal & 0.38 & 0.5 & 0.25 & 0.6 \\
\hline
\end{tabular}

Table (3) relation between total knowledge and total practice scores demographic characteristics of family caregivers and home environment, there was positive statistically significant relations between total knowledge of family caregivers and their age, $p=0.02$. There was a positive statistical significant total practice and their job, $p=0.08$. Also there was positive statistically significant relation between total knowledge of family caregivers and their education level, $p=0.07$.

\section{Discussion}

Related demographic characteristic of clients, Regarding client's age, the current result showed that less than half of clients aged more than or equal 25 years old. More than three quarters of the clients were male. Also more than third of client's cannot read and write. Regard clients job, the current study indicated that more than third of clients did not work. less than one hundred of clients didn't had insurance. Concerning to family members: The current study show less than one hundred of the clients' family consisted of 3 to less than 6 individuals.

Related demographic characteristic of family caregiver: Related to age, the current result showed that less than half family caregivers between aged from 20 to less than 30 years old and more than three quarters of family caregivers were male. Concerning family caregiver education level, the study indicated that less than to half family caregivers can't read and write. Also more than half of family caregivers were worked as hand craft.

Medical history of the clients and Home environment: Regarding chronic disease of clients: the current study show that more than three quarter of clients did not had chronic. Regarding injury site: The current study show that almost three quarters of clients had in the leg and more than three quarter of clients applied the machine from 1wk to less than 4 wks. Also less than one hundred of clients received medication as antibiotics analgesic and more than half of clients used public transportation.

Knowledge of family caregiver: Its was unsatisfactory, that more than three quarter and more than half related to definition, initiation and discontinuation of vacuum wound therapy. Also less than half of family care giver mentioned benefits.

Practice of family caregivers: Hundred percent of family care were satisfactory in all aspects selected about operating, aid in troubleshooting, remove jar, clears parts of machine practice related to hand washing during cleaned and disinfected the machine: The current study display that less than hundred unsatisfactory practice did not wash their hand and more than three quarter of family caregiver did not wear gloves.

\section{References}

1- ALFALAHI E., ASSABRI A. and KHADER Y.: Pattern of road traffic injuries in Yemen: A hospital-based study. Pan African Medical Journal, 29: 145. doi:10. 11604/ pamj.2018. 29.145.12974. This article is available online at: http://www.panafrican-med-journal.com/content/article/ 29/145/full/, 2018.

2- SINGH J., KOUR M.S., BILGUEES S. and KHON S. : Reasons for road traffic accidents victims in India, 2015.

3- ALI Z., ANJUM A., MAAJID S. and AHMAD D.: Evaluation of low-cost custom made VAC therapy compared with conventional wound dressings in the treatment of non-healing lower limb ulcers in lower socio-economic group patients of Kashmir valley. ournal of Orthopaedic Surgery and Research, 10: 183 DOI 10.1186/s13018-0150314-5, 2015.

4- FAGERDAHL M.: The Patient's Conceptions of Wound Treatment with Negative Pressure Wound Therapy" health care Healthcare, 2: 272-281, 2014.

5- ELTAYEBA H. and KASSEM R.: Negative-pressure wound therapy in pediatric extremity trauma: A singleinstitution experience http://www.ejs.eg.net on Friday, March 15, IP: 154.130.235.236], 2019. 
6- UPTON D. and ALEXANDER R.: The complexity of caring (Part 1): Detrimental health and well-being outcomes for caregivers of people with chronic wounds, 23 (3), 2015.

7- SUSAN M. RHEE M.: Negative Pressure Wound Therapy Technologies for Chronic Wound Care in the Home Setting Technology Assessment Report, in Johns Hopkins Uni- versity Evidence-based Practice Center, Project ID: WNDT0913, 2015.

8- OTHMAN D.: Negative Pressure Wound Therapy Literature Review of Efficacy, Cost Effectiveness, and Impact on Patients' Quality of Life in Chronic Wound Management and Its Implementation in the United Kingdom Plastic Surgery International, doi:10.1155/2012/374398, 2012.

\section{معلومات وممارسات مقدمى الرعاية بالأسرة

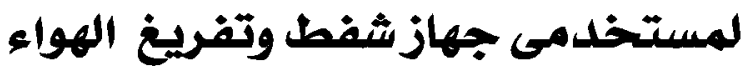

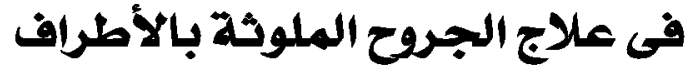

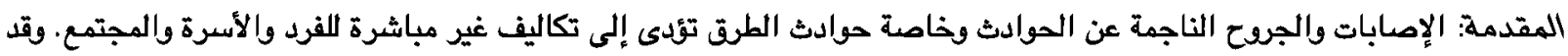

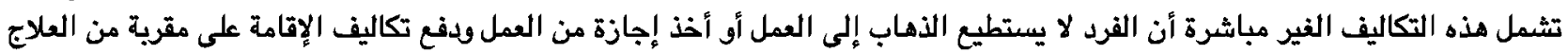

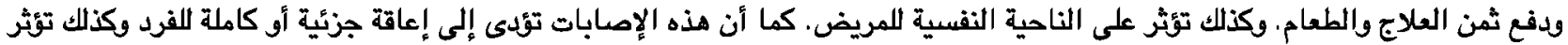

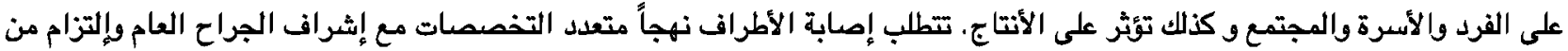
أخصائيين آخرين بما فى ذلك جراحى العظام والأوعية الدموية والتجميلية.

إن إستخدام جهاز شفط وتفريغ الهواء لعلاج الجرح الملوئة بالأطراف يعتبر التقنية المتقدمة والفعالة فى إلتئام الجرح وذلك بإستخدام

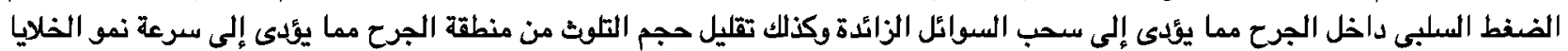

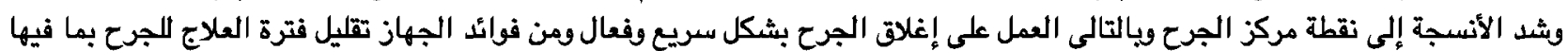

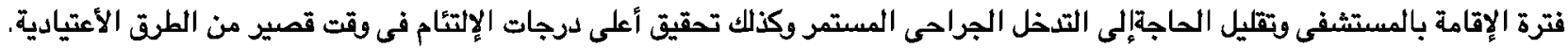
الهدف من البحث: يهدف هذا البحث إلى تقييم معلومات وممارسيات مقدمى الرعاية بالأسرة لمستخدمى جهاز شفط وتفريخ الهواء فى علاج الجرح الملوئة بالأطراف. 